\title{
7 THE TRANSYLVANIAN ISSUE: SWEDISH PERSPECTIVES (1944-1945)
}

\section{Marian-Alin Dudoi}

Independent Researcher, Email: marianalindudoi@yahoo.com

\begin{abstract}
:
The study refers to the approaches of the Transylvanian issue expressed by the Swede Gustav Bolinder in a "Svensk Tidskrift" article, volume XXXI, no. 9 of 1944. The Armistice Agreement between Romania and the United Nations, signed on September 12/13, 1944, admitted that Transylvania or most of this province to be reassigned to Romania. Suddenly, the Transylvanian issue had become one of the headlines in the world. Gustaf Bolinder, who had traveled in Romania in 1943, supported the Romanian rights in a book and press articles, both in Swedish (the article referred to in this paper dates from Autumn 1944). Another Swede, namely Arvid Fredborg, wrote comments that mostly criticized Bolinder's approaches. Bolinder's views and Fredborg's comments were dispatched by the USA Legation in Sweden to the State Department, in Washington DC, and studied by the author at the Central National Historical Archives of Romania, within the USA Microfilm Collection. As the Armistice Agreement between Hungary and the United Nations, signed on January 20, 1945, forbade any Hungarian claims on Transylvania only two choices remained: an independent Transylvania, an unrealizable project according to the United Nations but present in the international media, or its reintegration into Romania. The author considers that Bolinder's synthesis mastered, among non-Romanians and nonHungarians, the truth about Transylvanian interethnic relations at the end of World War II.
\end{abstract}

\section{Rezumat:}

Studiul se referă la analiza problemei transilvănene de către suedezul Gustaf Bolinder in articolul din "Svensk Tidskrift", volumul XXXI, nr. 9 din 1944. Convenția de Armistițiu dintre România și Natiunile Unite, încheiată în 12/13 septembrie 1944, a prevăzut ca Transilvania sau cea mai mare parte a ei să fie reunificată cu România. Deodată, problema transilvăneană devenise un subiect de știri în lume. Gustaf Bolinder, care călătorise în România în 1943, a susținut drepturile României într-o lucrare și în articole de presă, toate în limba suedeză (articolul, la care ne referim, datează din toamna anului 1944). Un alt suedez, numit Arvid Fredborg, a criticat de regulă analiza lui Bolinder. Opiniile lui Bolinder și comentariile lui Fredborg au fost 
innaintate de Legația S.U.A. din Suedia Departamentului de Stat, în Washington DC, și studiate de autor la Arhivele Naționale Istorice Centrale ale României, în cadrul Colecției de Microfilme S.U.A. Deoarece Convenția de Armistițiu dintre Ungaria și Națiunile Unite, încheiată în 20 ianuarie 1945, nu a permis dreptul Ungariei de a avea pretenții la Transilvania, au rămas două variante: o Transilvanie independentă, proiect nerealizabil datorită opoziției Națiunilor Unite, dar prezent în presa internațională, și reunificarea cu România. Autorul consideră că sinteza lui Bolinder a relevat cel mai bine, printre cei care nu erau români sau maghiari, adevărul despre relațiile interetnice în Transilvania la sfârșitul celui de-al Doilea Război Mondial.

Keywords: Hungary, Gustaf Bolinder, Arvid Fredborg, Transylvania, Romania, World War II

\section{Introduction}

By the Second Vienna Award of 30 August, 1940, Nazi Germany and Fascist Italy imposed to the Romanian Kingdom to reassign northern Transylvania to Hungary. The Soviet Union was not part of this deal and Edvard Beneš, the Czechoslovak President in exile, had revealed on March 10, 1944, after his trip to Moscow, in an interview to Daily Express, Joseph Stalin's agreement that entire Transylvania should be restored to Romania. ${ }^{1}$

The Soviet Union had already formed its own commission, led by the Deputy People's Commissar for Foreign Affairs, Maksim Maksimovitch Litvinov, in order to analyse the Transylvanian issue. On June 5, 1944, the Commission proposed the reassignment of entire Transylvania to Romania, as compensation for Bessarabia and Bukovina's loss in favour of the U.S.S.R.; a purpose of Soviet benevolence was the theory according to which Romania would become an ally of the Soviet Union, the latter being the only power capable to support Romania against Hungarian incessant claims. However, the Commission asserted that the Red Army should occupy Transylvania until the Soviet-Romanian collaboration would be clarified. ${ }^{2}$

Despite the provisions declaring the Second Vienna Award as void, article 19 of the Armistice Convention between Romania and the United Nations, signed in Moscow on September 12-13, 1944, specified that

\footnotetext{
${ }_{1}$ Marin Radu Mocanu, ed., România în anticamera Conferinței de Pace de la Paris. Documente (hereinafter RACPP) (Bucureşti, 1996), doc. no. 24, Report "Romania at the Peace Conference", 147.

2 Valeriu Florin Dobrinescu and Ion Pătroiu, Documente franceze despre Transilvania (1944-1947) (hereinafter DFT) (Bucureşti: Editura Vremea, 2001), 25-26.
} 
"Transylvania (or the greater part thereof) should be restored to Romania subject to confirmation at the peace settlement"; the latter part meant, for Romania, the reopening of the Transylvanian issue, namely the unpleasant possibility of revising the Trianon Treaty of 4 June $1920 .{ }^{3}$ During the socalled negotiations, which bore the Soviet imprint, the United States pleaded unsuccessfully for Hungary in the matter of some changes in the HungarianRomanian frontier and they continued to do until May 7, 1946. ${ }^{4}$

In this context, the Transylvanian issue frequently reappeared on the agenda of international diplomacy and media. Hungarians seized the moment and proposed in September 1944 that the liberated territories granted to Hungary by the Vienna Awards should be administered by the Grand Alliance. ${ }^{5}$ In October they began an active propaganda in order to convince the United Nations about the necessity of an independent Transylvanian Republic, continued by a new Parisian leaflet in December. ${ }^{6}$ Moreover, across the Atlantic, the Hungarian Americans developed on a larger scale the subjects of independence and changing borders. ${ }^{7}$

The liberation of northern Transylvania by the Romanian and Red Army was followed by the Soviet difficulties in accepting the Romanian administration and on November 12, 1944, the Allied Control Commission in Romania, led by the Soviet High Command, decided the withdrawal of the Romanian administration although Prime-Minister Sănătescu had

\footnotetext{
${ }^{3}$ Marin Radu Mocanu, ed., România - marele sacrificat al celui de al doilea război mondial, vol. I. (Bucureşti, 1994), 323.

"Agreement Between The Governments of United States of America, The United Kingdom, the Union of Soviet Socialist Republics, on the One Hand, and the Government of Rumania, on the Other Hand, Concerning an Armistice", http://avalon.law.yale.edu/wwii/rumania.asp, accessed on 22.10.2016.

4 Joseph F. Harrington, Bruce J. Courtney, Relații româno-americane (1940-1990), Traducere de Mihaela Sadovschi, Prefață de V. Fl. Dobrinescu (Iaşi: Institutul European, 2002), 72.

${ }^{5}$ DFT, doc. no. 3, Jean Vergé's dispatch no. 28 of 17.10.1944 from Berne, to Georges Bidault, French Minister of Foreign Affairs, with an addendum of Honti's Appeal, dated 30 September 1944, concerning the United Nations or Great Powers's control over the liberated territories, previously granted by the Vienna Awards, 82-84.

${ }_{6}$ Ibid., doc. no. 4, Leaflet for the Formation of the Republic of Transylvania (Paris, dated October 1944), and doc. no. VII, Leaflet of the Leading Committee for the Formation of the Republic of Transylvania, 85-86 and 92-94.

7 Marin Radu Mocanu, ed., România și armistițiul cu Națiunile Unite (hereinafter: RANU) (București, 1995), doc. no. 47, Crețianu's telegram of 29.01.1945 from Angora to Romanian Minister of Foreign Affairs; the content was sent by Pavel Pavel from Great Britain via the Czechoslovak Legation in Angora, 211.
} 
received the official notification in the evening of the following day. ${ }^{8}$ The initial deadline was on 12 November, 7 p.m., but Sănătescu tried to delay it in order to prepare the necessary trains. ${ }^{9}$ On November 14 , the Soviet High Command, on behalf of the Allied Control Commission in Romania, took over the entire administration. ${ }^{10}$ Sănătescu's protests met the refusal of the omnipotent Soviets. ${ }^{11}$ And this happened although Burton Y. Berry, United States Representative in Romania, and Frank Gardiner Wisner, head of Office of Strategic Services operations in Southeastern Europe, praised the Romanian war effort for the Allies during an invitation to lunch, on November 20, hosted by Patrik Carl Reinhold Reuterswärd, Swedish Minister in Bucharest. ${ }^{12}$ On October 26, 1944, the Soviet High Command had already decided the disbandment of the so-called Iuliu Maniu Guards by accusing them of Fascism, although even the National Liberal Party, led by Constantin (Dinu) I.C. Brătianu, protested, a remarkable aspect given that Iuliu Maniu was the leader of the National Peasant Party. ${ }^{13}$

On December 1, 1944 the Soviets created the Central Advisory Council of the National Democratic Front in northern Transylvania, consisting of 46 local members, in order to meet the inhabitants' perspectives. Still, the Soviets had the intention to allow the re-unification with Romania. ${ }^{14}$

8 DFT, 12.

RANU, Sănătescu's Letter of 19.11.1944 to General Vinogradov, 103.

Valeriu Florin Dobrinescu, "Frontiera de Vest a României în politica Marilor Puteri (12/13 septembrie 1944-10 februarie 1947)," in Gabriel Bădărău, ed., Itinerarii istoriografice. Profesorului Leonid Boicu la împlinirea vîrstei de 65 de ani (Iași, 1996), 280.

${ }^{9}$ Radu Ciuceanu et al., eds., Misiunile lui A.I. Vâş̧inski în România. (Din istoria relațiilor românosovietice, 1944-1946). Documente secrete (Bucureşti, 1997), doc. no. 15, Record of VinogradovSănătescu Meeting of 12.11.1944, 89.

10 Idem, Doru Tompea, România la cele două Conferințe de Pace de la Paris (1919-1920, 1946-1947). Un studiu comparativ (Focșani: Editura Neuron, 1996), 103.

Ion Calafeteanu et al., Istoria politicii externe românești în date (București: Editura Enciclopedică, 2003), 342.

11 RANU, doc. no. 22, 103-106.

Cf. Marian-Silviu Miloiu, O istorie a Europei Nordice și Baltice, vol. II, De la Războiul Rece la Era Globalizării (Târgoviște: Editura Cetatea de Scaun, 2005), 128.

12 Valeriu Florin Dobrinescu, România și organizarea postbelică a lumii (1945-1947), (București, Editura Academiei, 1988), 91.

13 Ibid., 68.

Dobrinescu 1996, 278.

14 Mihály Zoltán Nágy, Gábor Vincze, eds., Autonomiști și centralişti. Enigmele unor decizii istorice. Transilvania de Nord din septembrie 1944 până în martie 1945, (Cluj-Napoca, Fundația 


\section{Bolinder's Statements}

Swedish anthropologist Gustaf Bolinder, who had traveled in Romania in 1943, pleaded for Romanian rights to Transylvania in the review "Svensk Tidskrift" ["Swedish Review"], volume XXXI, no. 9, 1944; the United States' Legation in Stockholm translated the article entitled "Should Transylvania Become an Independent State?" from Swedish into English, and enclosed it in a dispatch addressed to the State Department on Febuary 20, 1945. Bolinder had already defended the Romanian viewpoints several times in the Swedish newspaper "Dagens Nyheter" (July 1943) and had also published a book entitled "Rumanian Issues. The Question of Transylvania" in Swedish and Finnish (1944). ${ }^{15}$

Other European journalists or historians also embraced the idea of a Romanian Transylvania during World War II, among them Hugh SetonWatson in his book "Eastern Europe between the Wars (1918-1941)", Peter Mattheros in the article "The future of Transylvania" in the "Contemporary Review" or the Swiss press. ${ }^{16}$

Bolinder noted in the review "Svensk Tidskrift" that all analysts rejected the idea of dividing Transylvania on ethnic criteria both due to the mixture of races and to transmigration and humanitarian reasons but the majority of analysts supported the idea of an independent state and double citizenship (Transylvanian and that of the ethnic state), especially because the province's culture and civilization belonged to the Hungarian and German minorities (sic!) and because the state's existence should be

Centrului de Resurse pentru Diversitate Etnoculturală - Foundation for Ethnocultural Diversity Center -), 2008, 72-73.

15 Central National Historical Archives of Romania (Bucharest), U.S.A. Microfilm Collection, Reel no. 664, Dispatch no. 5016 of 20.02.1945, addressed by Herschel Vespasian Johnson, U.S.A. Minister in Stockholm, to U.S.A. State Secretary (hereinafter Johnson's dispatch), frames 856-857.

George Ghimpu, "Conştiința națională a românilor moldoveni", https://www.scribd.com/document/43922559/Con\%C8\%99tiin\%C8\%9Ba-

na\%C8\%9Bional\%C4\%83-a-romanilor-moldoveni-Gheorghe-Ghimpu (accessed on 16.10.2016).

Alexandru Popescu, 'The Romanian-Finnish Cultural Relations: History, Trends, Bibliography', Revista Română de Studii Baltice şi Nordice/The Romanian Journal for Baltic and Nordic Studies 1 (1/2009): 118.

16 RANU, doc. no. 52, Raoul Bossy's Letter of 12.02.1945, from Geneva, to C. Vişoianu, Romanian Minister of Foreign Affairs, 227.

Valeriu Florin Dobrinescu, România și Ungaria de la Trianon la Paris (1920-1947). Bătălia diplomatică pentru Transilvania (București: Editura Viitorul Românesc, 1996), 218. 
guaranteed by the United Nations, the latter verifying whether economic and social equality and cultural autonomy were ensured.

Bolinder rejected this project as each ethnicity had contributed to Transylvania's overall culture and therefore no culture could have greater importance than the others. He wondered what would be the reaction of the Finnish people if the Swedish minority wanted to form its own state; the Romanian majority ( $58 \%$ according to Bolinder) had the right to be opposed to an independent Transylvania. If an independent Transylvania's treaty forbade the unification with Romania, the Transylvanian Romanians will do as much as they can to unite with Romania, despite the provisions (Bolinder gave as an example the forbiddance of the unification between Germany and Austria stipulated by the Paris Peace Conference of 1919-1920 which proved to be unrealisable). A comparison with Switzerland was irrelevant, argued Bolinder, as the Swiss nations decided to sincerely live together. The history of Transylvania represented a continuous struggle of the Romanian majority against the Hungarian ruling class. Subsequently, the Swedish anthropologist denied the possibility of any sincere cooperation between Romanians and Hungarians in Transylvania as the Hungarians publicly maintained their right to rule Transylvania because of their higher cultural level; Bolinder accepted the idea of a higher cultural level but argued it was not the only relevant item. The idea of autonomy within Romania had also little support amongst Transylvanian Hungarians but Hungary usually proposed it. An independent or autonomous Transylvania would name a Romanian as ruler because Hungarians were and would be a minority, but such a solution would raise many majority-minority conflicts and, therefore, he considered it an "artificial state" ${ }^{17}$

According to some authors, the German minority would refuse to live again in Romania but Bolinder noted the Germans accepted the 1918 unification and they would not embrace the idea of an independent or autonomous Transylvania, the latter viewpoint being supported by his own voyage. The Swedish anthropologist decreased the importance of Swabians in the future as he expected them to disappear as an ethnic group. According to the principles of democracy, a minority accepted to be ruled by a majority but not at the expense of discrimination. Serious complaints did not appear from the part of the German, the Greek, the Turkish or the Armenian

17 Johnson's dispatch, Addendum, 860-862. 
minorities. The only complaints belonged to irredentists who maintained a state of agitation in south-eastern Europe. ${ }^{18}$

The Romanian government would probably refuse even a minor frontier adjustment in Hungary's benefit, as it had been inclined to accept adjustments until the Second Vienna Award had come into force. For Bolinder, an independent Transylvania was not recommended from the economic point of view because of the tendency towards the formation of greater economic entities as Europe was divided in mostly small states. An independent Transylvania would represent an open wound and keeping the wound in such a manner would delay the cure! The Second Vienna Award should be cancelled and revised and he congratulated the Allies for this intention. ${ }^{19}$

\section{Fredborg's Comments}

Arvid Fredborg had to deal with the contemporary issues of Central Europe during his activity as a press correspondent in Berlin (subsequently, he published the book "Behind the Steel Wall. A Swedish Journalist in Berlin, 1941-1943"; In 1943, the USA Legation in Stockholm made a synthesis of the book, entitled "Attitude of an Able Swedish Commentator toward War and Postwar Problems", for the State Department). ${ }^{20}$

Arvid Fredborg proved to be a fierce critic of Bolinder. Fredborg mentioned the Romanian difficulty when meeting the Armistice Agreement's requirements which could affect the Soviet support for Romanian claims. The Hungarian percent of the population could rise to 30, possibly between 25 and 30, but not 25 as Bolinder claimed it. Any comparison with Swedish or Finland is irrelevant since Transylvania has clear geographic boundaries on three sides and a tradition as an autonomous area. ${ }^{21}$ Fredborg apparently forgot that Transylvania had lost his autonomy in 1867, recovering it only for a year and a half, in 1918-1920.

He didn't believe that the Romanians would get the political majority and considered that there existed a struggle between regions or between towns and the central authority, namely between Saxon towns and Hungarian rule. The conflict between Hungarian landlords and Romanian

\footnotetext{
18 Ibid., 862.

19 Ibid., 863.

20 Ibid., 856.

${ }^{21}$ Ibid., 863-864.
} 
peasants had a social significance, but it happened also between Hungarian landlords and Hungarian peasants. As for the extinction of Swabians, he accused Bolinder of confusing them with a small group of Swabians, from the Szatmar District. He didn't believe that the Saxon towns and Swabian peasants (sic!) supported Romanian views, especially considering the possibility of being a part of a Communist Romania while Hungary or independent Transylvania remained democratic. However, he admitted Saxons or Swabians' options would have no relevance if a new Vienna Award imposed by Moscow kept them as part of a Soviet rule on Romania. ${ }^{22}$ Another one of Fredborg's mistakes regarded the probability of the German minority's support for Hungary and Hungarian Romanians in order to avoid Communism as reports proved the spread of Communist ideology on a larger scale among Hungarians than amongst Romanians, the former being easier to convince due to the fact that they lived in towns, especially those Hungarians from northern Transylvania (the so-called "Northern Transylvanian Republic", which was, however, north-eastern Transylvania from a geographical point of view). ${ }^{23}$

Fredborg did not agree with Bolinder in the matter that not all Romanians would vote against an independent Transylvania based on the assumption that Transylvanian Romanians were different from their kinsmen inhabiting the Old Kingdom. The German minority could disregard Romanians to a higher degree as they were a favoured minority until 1940 and the Romanians would behave less nicely in the future due to their support for Nazi Germany. Moreover, when criticizing Bolinder's views about the minorities' fair treatment, Fredborg did not accept the Greeks as a minority group (12,000 persons) as they were nearly assimilated and as they had until recently been part of the Romanian ruling class due to their ancestry from Phanariots. ${ }^{24}$

\section{The Transylvanian Issue in the Aftermath of World War II}

Article 19 of the Armistice Convention between Hungary and the United Nations, signed in Moscow on January 20, 1945, declared void the

\footnotetext{
22 Ibid., 864-866.

23 DFT, 15.

Stefano Bottoni, Transilvania roșie: comunismul românesc și problema națională (1944-1965) (ClujNapoca: Editura Institutului pentru Studierea Problemelor Minorităților Naționale: Kriterion, 2010), 52.

24 Johnson's dispatch, Addendum, 866-867.
} 
Second Vienna Award of 30 August 1940 and deeply affected Hungary's chances to obtain a part of Transylvania at the Peace Conference. ${ }^{25}$ Among the Hungarians, an independent Transylvania, even under Soviet protectorate, remained the best option. ${ }^{26}$

The new Romanian Government, led by the puppet Petru Groza, contacted the Soviet Government on 8 March, 1945 in order to reinstate northern Transylvania within the borders of Romanian State, which Joseph Stalin accepted the very next day. ${ }^{27}$ A month before, when Constantin Vișoianu, Romanian Minister of Foreign Affairs, had inquired Anatoli Pavlov, Political Advisor of Soviet High Command, about the instalment of Romanian Administration in the region, Pavlov demanded that Romania should first meet all the provisions of the Armistice Agreement; informally, this meant a pro-Soviet Government. ${ }^{28}$

In the aftermath of World War II, the Soviet Union continued to trade northern Transylvania for the maintenance of a pro-Soviet Government in Romania. The United States tried to give the Hungarian government stemming from a real coalition a small part of Transylvania but even the British, which initially supported the Americans at the London Council of Foreign Ministers (September 1945), denied it in the spring of 1946 and informed King Michael of Romania that they did not approve of the American views when he specifically inquired of them on this topic. ${ }^{29}$

\footnotetext{
25 RACPP, doc. no. 24, Report "Romania at the Peace Conference", 148.

Ibid., doc. no. 26, Romanian Government's "Report concerning the Conditions of the Peace Treaty between Romania and the Allied Powers and Hungary's Claims", 168.

Calafeteanu 2003, 343.

"Agreement Concerning an Armistice Between the Union of Soviet Socialist Republics, the United Kingdom of Great Britain and Northern Ireland, and the United States of America on One Hand And Hungary on the Other", http://avalon.law.yale.edu/wwii/hungary.asp accessed at 22.10.2016.

26 Dobrinescu, Tompea 1996, 102-103.

27 Dinu C. Giurescu, "Revenirea administrației româneşti în nordul şi estul Transilvaniei. Prevederile Convenției de Armistițiu şi interpretarea lor," in Istoria Românilor, vol. IX, România in anii 1940-1947, ed. Dinu C. Giurescu (Bucureşti: Editura Enciclopedică, 2008), 552.

28 RANU, doc. no. 50, Pavlov's report of 9.02.1945 to Soviet Ministry of Foreign Affairs, 224.

${ }^{29}$ Mihály Fúlop, Pacea neterminată. Consiliul Miniştrilor Afacerilor Externe şi tratatul de pace ungar (1947), Traducere de Ana Scarlat, Postfață de Cătălin Turliuc (Iaşi: Institutul European, 2007), 151-157.

Cf. Paul D. Quinlan, "The U.S. and Transylvania During World War II," in Romania Between East and West. Historical Essays in Memory of Constantin C. Giurescu, Stephen Fischer-Galați et al., eds. (New York: East European Monographs, Boulder, Distributed by Columbia University Press), 1982, 377.
} 
Richard Franassovici, Romanian Minister in London, also believed in British sincerity. ${ }^{30}$ For the British, the existence of the Romanian monarchy represented the most important impediment to Communism in a period when British influence vanished in Romanians' eyes. ${ }^{31}$ This prevented the Romanian Communists from criticizing the King, as he was a relative of King George VI of Great Britain; moreover, the United Kingdom also knew that it couldn't match the Soviet Union who supported Romania (ruled by the obedient Groza government), and not Hungary. Consequently, the Paris Peace Conference of 1946 and the Peace Treaties with Romania and Hungary signed of 10 February 1947 admitted the Romanian rights to the northeastern Transylvania.

\section{Conclusion}

Gustaf Bolinder denied the viability of an independent Transylvania by offering multiple reasons based on the Romanian ethnic majority and supported the idea of a Transylvania re-united with Romania as he considered that Romania had offered a fair treatment of minorities.

Arvid Fredborg promoted the idea of autonomy, thinking of Transylvanian Romanians' opposition to centralism, but this solution proved unreliable as interethnic tension was higher than ever before and surpassed social and political approaches.

Bolinder's considerations mirrored the voice of the Romanian people as his writings fairly concluded the option of dominant Transylvanian ethnic group of Romanians for a Transylvania within Romania. Bolinder's book and press articles provided to the Nordic community a scientific view on the Transylvanian issue at the end of World War II.

\footnotetext{
30 Gheorghe Buzatu, Stela Acatrinei, Daniel Onişor, Horia Dumitrescu, România în ecuația războiului şi a păcii (1939-1947), vol. II (Iaşi: Editura Tipo Moldova, 2009), 52.

Cf. Cezar Stanciu, "Contribuții la istoria relațiilor postbelice româno-britanice (1947-1954)," Anuarul Institutului de Istorie A.D. Xenopol XLV (2008): 245.

31 Mark Percival, "Politica britanică față de România în 1946," in Anale Sighet, vol. 3, Anul 1946începutul sfârşitului (instituții, mentalități, evenimente). Comunicări prezentate la Simpozionul de la Sighetu Marmației (7-9 iunie 1997) (Bucureşti: Fundația Academia Civică, 1996), 88.

Idem, "Politica britanică față de România în 1947," in Anale Sighet, vol. 5, Anul 1947-căderea cortinei. Comunicări prezentate la Simpozionul de la Sighetu Marmației (20-22 iunie 1997), (Bucureşti: Fundația Academia Civică, 1997), 690-691.
} 


\section{References:}

\section{A. Archives}

Central National Historical Archives of Romania (Bucharest), USA Microfilm Collection, Reel no. 664.

\section{B. Published Documents}

Ciuceanu, Radu et al., eds. Misiunile lui A.I. Vâş̧inski în România. (Din istoria relațiilor româno-sovietice, 1944-1946). Documente secrete. București, 1997.

Dobrinescu, Valeriu Florin, Ion Pătroiu. Documente franceze despre Transilvania (1944-1947). Bucureşti: Editura Vremea, 2001.

Mocanu, Marin Radu, ed. România - marele sacrificat al celui de al doilea război mondial, vol. I. Bucureşti, 1994.

Mocanu, Marin Radu. România și armistițiul cu Națiunile Unite. București, 1995.

Mocanu, Marin Radu. România în anticamera Conferinței de Pace de la Paris. Documente. Bucureşti, 1996.

\section{Sources}

Bottoni, Stefano. Transilvania roșie: comunismul românesc și problema națională (1944-1965). Cluj-Napoca: Editura Institutului pentru Studierea Problemelor Minorităților Naționale: Kriterion, 2010.

Buzatu, Gheorghe, Stela Acatrinei, Daniel Onişor, Horia Dumitrescu, România în ecuația războiului şi a păcii (1939-1947), vol. II (Iaşi: Editura Tipo Moldova), 2009.

Calafeteanu, Ion et al., Istoria politicii externe românești în date. București: Editura Enciclopedică, 2003.

Dobrinescu, Valeriu Florin, "Frontiera de Vest a României în politica Marilor Puteri (12/13 septembrie 1944-10 februarie 1947)." In Gabriel Bădărău, ed., Itinerarii istoriografice. Profesorului Leonid Boicu la împlinirea vîrstei de 65 de ani.. Iași, 1996, 273-305.

Idem, România și Ungaria de la Trianon la Paris (1920-1947). Bătălia diplomatică pentru Transilvania. București: Editura Viitorul Românesc, 1996.

Idem, România și organizarea postbelică a lumii (1945-1947). București: Editura Academiei, 1988. 
Idem, Doru Tompea. România la cele două Conferințe de Pace de la Paris (19191920, 1946-1947). Un studiu comparativ. Focșani: Editura Neuron, 1996.

Giurescu, Dinu C.“Revenirea administrației româneşti în nordul şi estul Transilvaniei. Prevederile Convenției de Armistițiu şi interpretarea lor." In Istoria Românilor, vol. IX, România în anii 1940-1947. Ed. Dinu C. Giurescu, Bucureşti: Editura Enciclopedică, 2008, 547-553.

Harrington, Joseph F., Bruce J. Courtney. Relații româno-americane (19401990), Traducere de Mihaela Sadovschi, Prefață de V. Fl. Dobrinescu. (Iaşi: Institutul European), 2002.

Fúlop, Mihály. Pacea neterminată. Consiliul Miniştrilor Afacerilor Externe şi tratatul de pace ungar (1947), Traducere de Ana Scarlat, Postfață de Cătălin Turliuc. Iaşi: Institutul European, 2007.

Miloiu, Marian-Silviu. O istorie a Europei Nordice și Baltice, vol. II, De la Războiul Rece la Era Globalizării. Târgoviște: Editura Cetatea de Scaun, 2005.

Nágy, Mihály Zoltán, Gábor Vincze, eds. Autonomiști și centraliști. Enigmele unor decizii istorice. Transilvania de Nord din septembrie 1944 până în martie 1945. Cluj-Napoca: Fundația Centrului de Resurse pentru Diversitate Etnoculturală [Foundation for Ethnocultural Diversity Center], 2008.

Percival, Mark.“Politica britanică față de România în 1946." In Anale Sighet, vol. 3, Anul 1946-începutul sfârşitului (instituții, mentalități, evenimente). Comunicări prezentate la Simpozionul de la Sighetu Marmației (7-9 iunie 1997). Bucureşti: Fundația Academia Civică, 1996, 82-103.

Idem. "Politica britanică față de România în 1947." In Anale Sighet, vol. 5, Anul 1947-căderea cortinei. Comunicări prezentate la Simpozionul de la Sighetu Marmației (20-22 iunie 1997). Bucureşti: Fundația Academia Civică, 1997, 685-691.

Popescu, Alexandru. 'The Romanian-Finnish Cultural Relations: History, Trends, Bibliography.' Revista Română de Studii Baltice şi Nordice/ The Romanian Journal for Baltic and Nordic Studies 1 (1/2009): 115-130.

Quinlan, Paul D.“The U.S. and Transylvania During World War II." In Romania Between East and West. Historical Essays in Memory of Constantin C. Giurescu, Stephen Fischer-Galați et al., eds. New York: East European Monographs, Boulder, Distributed by Columbia University Press, 1982, 369-383. 
Stanciu, Cezar. "Contribuții la istoria relatiilor postbelice româno-britanice (1947-1954)." Anuarul Institutului de Istorie A.D. Xenopol XLV (2008): 243-259.

\section{Web postings:}

"Agreement Between The Governments of United States of America, The United Kingdom, the Union of Soviet Socialist Republics, on the One Hand, and the Government of Rumania, on the Other Hand, Concerning an Armistice", http://avalon.law.yale.edu/wwii/rumania.asp, accessed at 22.10.2016.

"Agreement Concerning an Armistice Between the Union of Soviet Socialist Republics, the United Kingdom of Great Britain and Northern Ireland, and the United States of America on One Hand And Hungary on the Other", http://avalon.law.yale.edu/wwii/hungary.asp accessed on 22.10.2016.

George Ghimpu, "Conştiința națională a românilor moldoveni", https://www.scribd.com/document/43922559/Con\%C8\%99tiin\% C8\%9Ba-na\%C8\%9Bional\%C4\%83-a-romanilor-moldoveni-

Gheorghe-Ghimpu (accessed on 16.10.2016). 